\author{
MATEUSZ JANAS \\ Uniwersytet Ekonomiczny w Krakowie, Polska \\ Cracow University of Economics, Poland
}

\title{
Konkurencyjność i innowacyjność przedsiębiorstw sektora MŚP w Polsce
}

\section{Competitiveness and Innovation of Enterprises of the SME Sector in Poland}

\begin{abstract}
Streszczenie: W dobie gospodarki XXI wieku, określanej mianem gospodarki opartej na wiedzy (GOW), konkurencyjność przedsiębiorstwa i jego pozycja zależy w dużej mierze od wprowadzonych innowacji w oferowanych produktach i usługach. W gospodarce krajów Unii Europejskiej podmiotami, które określa się jako jej siłę napędową, są przedsiębiorstwa zaliczane do sektora MŚP (mikro-, małe i średnie przedsiębiorstwa). Z tego też względu w niniejszej publikacji poruszona została tematyka konkurencyjności i innowacyjności tych przedsiębiorstw w Polsce po jej przystąpieniu do struktur UE, tj. po 2004 roku. W artykule podjęto rozważania na temat istoty konkurencyjności oraz innowacyjności przedsiębiorstwa, ze wskazaniem na czynniki kształtujące wpływ innowacyjności na pozycję konkurencyjną. Realizacja zmian, jakie łączą się z działalnością innowacyjną przedsiębiorstw, rozumiana jest jako zdolność do wdrożenia ulepszeń produktowych, procesowych, organizacyjnych oraz marketingowych. W artykule przedstawiono rodzaje innowacji oraz ich możliwe efekty, które oddziałują na pozycję przedsiębiorstwa na konkurencyjnym i dynamicznie zmieniającym się rynku gospodarczym.
\end{abstract}

\begin{abstract}
In the 21st century economy, referred to as the knowledge-based economy (KBE), the competitiveness of a business and its position depends, to a large extent, on innovations in the products and services it offers. In the EU countries, the entities that are referred to as its "driving force" are businesses belonging to the SME sector (small and medium sized enterprises). Therefore, the subject matter of this study is the competitiveness and the innovativeness of those enterprises in Poland after the country's accession to the EU structures, i.e. after 2004. The paper discusses the very notion of innovativeness and competitiveness of a business, pointing to the factors shaping the influence of innovation on its competitive position. The realisation of changes that are connected with the innovative activity of a businesses is understood as the ability to implement improvements regarding products, processing, marketing and organisation. The paper presents the types of innovations, as well as their possible effects that affect the position of a business on the competitive market that is changing dynamically.
\end{abstract}

Słowa kluczowe: innowacyjność; konkurencyjność; przedsiębiorstwa; sektor MŚP Keywords: competitiveness; enterprises; innovation; SME sector

Otrzymano: 9 stycznia 2019

Received: 9 January 2019

Zaakceptowano: 31 października 2019

Accepted: 31 October 2019 
Sugerowana cytacja / Suggested citation:

Janas, M. (2019). Konkurencyjność i innowacyjność przedsiębiorstw sektora MŚP w Polsce. Prace Komisji Geografii Przemysłu Polskiego Towarzystwa Geograficznego, 33(4), 176-194. doi: 10.24917/20801653.334.11

\section{WSTĘP}

Działalność innowacyjna przedsiębiorstw, jak również szeroko rozumiane innowacje są jednym z głównych tematów nauki, a także praktyki gospodarczej. Ważnym determinantem warunkującym odpowiedni rozwój gospodarki w danym rejonie, kraju, przedsiębiorstwie jest właśnie innowacyjność. Tempo i kierunki rozwoju gospodarczego są uwarunkowane podjęciem działalności innowacyjnej. Coraz częściej innowacje są powodem podejmowania współpracy między przedsiębiorstwami w kraju z podmiotami zagranicznymi (Mazur-Wierzbicka, 2015). Polska jest w okresie istotnych zmian gospodarczo-społecznych, które mają również wpływ na sferę polityki innowacyjnej. Udział w podejmowanych innowacjach wzrasta, co oznacza, że przedsiębiorstwa coraz częściej budują strategię opartą na polityce innowacyjnej (GUS, 2017: 1-2).

Działania innowacyjne i szeroko pojęta współpraca w tym zakresie są szczególnie ważne w przypadku małych i średnich przedsiębiorstw funkcjonujących w gospodarce polskiej i europejskiej. Podmioty z sektora MŚP wpływają na rozwój gospodarki krajowej, a także europejskiej (Poznańska, 2016: 143-144).

Ważne zatem jest rozpoznanie poziomu działalności innowacyjnej przez polskie i europejskie przedsiębiorstwa. Jako cel opracowania przyjęto określenie działalności przedsiębiorstw sektora MŚP, nakładów na działalność innowacyjną oraz przyczyny braku innowacyjności.

Rozważania podjęte w artykule opierają się na porównaniu raportów Głównego Urzędu Statystycznego, Eurostatu, Polskiej Agencji Rozwoju Przedsiębiorczości oraz na opracowaniu literatury przedmiotu w zakresie innowacji podejmowanych przez przedsiębiorstwa sektora MŚP.

\section{DZIAŁALNOŚĆ INNOWACYJNA PRZEDSIĘBIORSTW MŚP w POLSCE I UNII EUROPEJSKIEJ}

W dobie stale zmieniających się uwarunkowań rynkowych oraz zmiennych potrzeb klientów przedsiębiorstwa chcące pozostać na rynku bez wątpienia muszą się do nich dostosować. Nieustanny wyścig po sukces, w którym biorą udział współczesne organizacje, doprowadza do sytuacji, w której zarządzający dla zdobycia pożądanej przewagi konkurencyjnej starają się zaproponować odbiorcom rozwiązania nowatorskie. Wśród teoretyków i praktyków biznesu panuje zgoda, że obecnie najważniejszym czynnikiem budowy przewagi konkurencyjnej jest innowacja.

W literaturze przedmiotu istnieje wiele definicji innowacji. Słowo „innowacja” pochodzi z języka łacińskiego, od słowa innovato, tłumaczonego jako odnowienie (Janasz, Kozioł, 2007: 12). Definicje tego pojęcia były licznie wykorzystywane przez teoretyków makroekonomii, specjalistów od zarządzania i ekonomiki przedsiębiorstw, a także przez naukowców zajmujących się innymi naukami (Świtalski, 2005: 80). Innowacja w rozumieniu potocznym oznacza coś nowego, innego od dotychczasowych rozwiązań. Jest kojarzona z potrzebą zmiany na lepsze. 
Kolejnym ważnym zagadnieniem, które oddziałuje na współczesne przedsiębiorstwa, jest konkurencyjność. Postępujące procesy globalizacyjne oraz deregulacja rynków powodują większe natężenie konkurencji. Przedsiębiorstwa, aby mogły zdobyć pożądaną pozycję konkurencyjną, muszą charakteryzować się konkurencyjnością.

W literaturze i biznesie zainteresowanie zagadnieniem konkurencyjności jest zrozumiałe, a tendencja ta wciąż się utrzymuje. Głównym jego powodem jest postępujący rozwój techniczny, technologiczny, transportowy oraz rosnąca atrakcyjność inwestycyjna poszczególnych gospodarek. Determinanty te powodują zaostrzenie się warunków i reguł działania na rynku, stawiając przed przedsiębiorstwami coraz to nowe wyzwania. Początkowo pojęcie konkurencyjności wprowadzone zostało do zbioru pojęć politycznych w kontekście makroekonomii. Nie chodziło o rzeczownik pochodzący od czasownika „konkurować”, lecz o konkretną cechę systemu gospodarczego, która umożliwia porównanie z innymi gospodarkami (Świtalski, 2005). W 1995 roku brytyjskie Ministerstwo Handlu i Przemysłu wyjaśniało konkurencyjność odnoszącą się do pojedynczych przedsiębiorstw jako zdolność do wytworzenia odpowiednich dóbr i usług w odpowiedniej jakości, po odpowiedniej cenie oraz w odpowiednim czasie. Mikroekonomiczne znaczenie konkurencyjności sprowadza się do zaspokojenia potrzeb nabywcy w wydajny sposób oraz sprawniej niż inne przedsiębiorstwa (Świtalski, 2005: 165-166).

Problematyka innowacji jest popularną dziedziną wśród różnych badaczy. Kompleksowy charakter innowacji pozwala na podejmowanie badań i analiz, które mogą odnosić się do wielu aspektów i dziedzin, np. ekonomii, marketingu, zarządzania i organizacji, psychologii czy inżynierii. Rozważania są prowadzone na poziomie mikro: w odniesieniu do poszczególnych produktów i usług, branż i sektorów gospodarki, a także na poziomie makro: w ujęciu regionalnym, krajowym i międzynarodowym. Wzrost zainteresowania problematyką innowacji jest wynikiem rosnącej świadomości znaczenia przewagi konkurencyjnej budowanej w oparciu o wiedzę i nowoczesne rozwiązania produktów czy usług (Skórska, 2016: 128-129).

Integracja Unii Europejskiej oraz procesy globalizacji przyczyniają się do wzrostu konkurencji między podmiotami gospodarczymi. Przedsiębiorstwa, aby utrzymać dobrą pozycję konkurencyjną na rynku, muszą nieustannie się rozwijać oraz dostosować działalność do zmiennych warunków otoczenia. Efektywność przedsięwzięć innowacyjnych jest uzależniona od dobrego wykorzystania wielu czynników o charakterze endogenicznym, pochodzących z wnętrza przedsiębiorstwa, jak też egzogenicznych, wynikających z otoczenia gospodarczego, kulturowego czy administracyjnego. Nowoczesna gospodarka zwiększa rolę wiedzy, informacji oraz zaawansowanych umiejętności (Kijek, 2013: 94).

Głównym źródłem informacji statystycznych o gospodarce polskiej w zakresie działalności innowacyjnej jest Główny Urząd Statystyczny (GUS), który cyklicznie publikuje opracowania dotyczące działalności innowacyjnej podmiotów gospodarczych (GUS, 2015, 2016, 2017). W publikacji kompleksowo przedstawione są wyniki badań z zakresu innowacji przedsiębiorstw, prowadzone w oparciu o standardową międzynarodową metodologię Oslo Manual (2005: 46).

Klasyfikowanie innowacji jest trudnym zadaniem, ponieważ są one powiązane z wieloma obszarami. Sprawia to, że poszczególne rodzaje innowacji możemy klasyfikować do kilku grup jednocześnie. W literaturze przedmiotu możemy spotkać różne rodzaje podziału innowacji. Warto więc zwrócić uwagę na najszerszy podział, który 
obejmuje innowacje produktowe, procesowe, marketingowe oraz organizacyjne. Istnieje również podział dychotomiczny (Głuszczuk, 2016), który dzieli innowacje pod względem technologii - na procesowe i produktowe. Nie uwzględniono w tym podziale innowacji w innych obszarach, takich jak zaawansowane techniki zarządzania, innowacje w marketingu, zmiany o charakterze estetycznym czy twórcze modyfikacje przedsiębiorstwa. Podział o szerszym spectrum będzie brał pod uwagę większą liczbę przedsiębiorstw sektora MŚP, które niekoniecznie zajmują się technologiami, a które wdrażają innowacje w innych obszarach, co może prowadzić do poprawy ich pozycji na rynku.

Przedsiębiorstwa sektora MŚP wprowadzające nowe rozwiązania mogą się rozwijać i być konkurencyjne na rynku. Efekty, jakie firmy uzyskują z wprowadzenia nowych rozwiązań, mogą być różne. Innowacje powodują nie tylko zamierzone skutki, ale również niezamierzone, i to w różnych sferach (rycina 1). Pozytywne skutki mogą być związane z polepszeniem pozycji konkurencyjnej na rynku, natomiast negatywne mogą dotyczyć środowiska naturalnego czy uczestników procesu innowacyjnego (Motyka, 2011: 162).

Rycina 1. Strefy oddziaływań innowacji

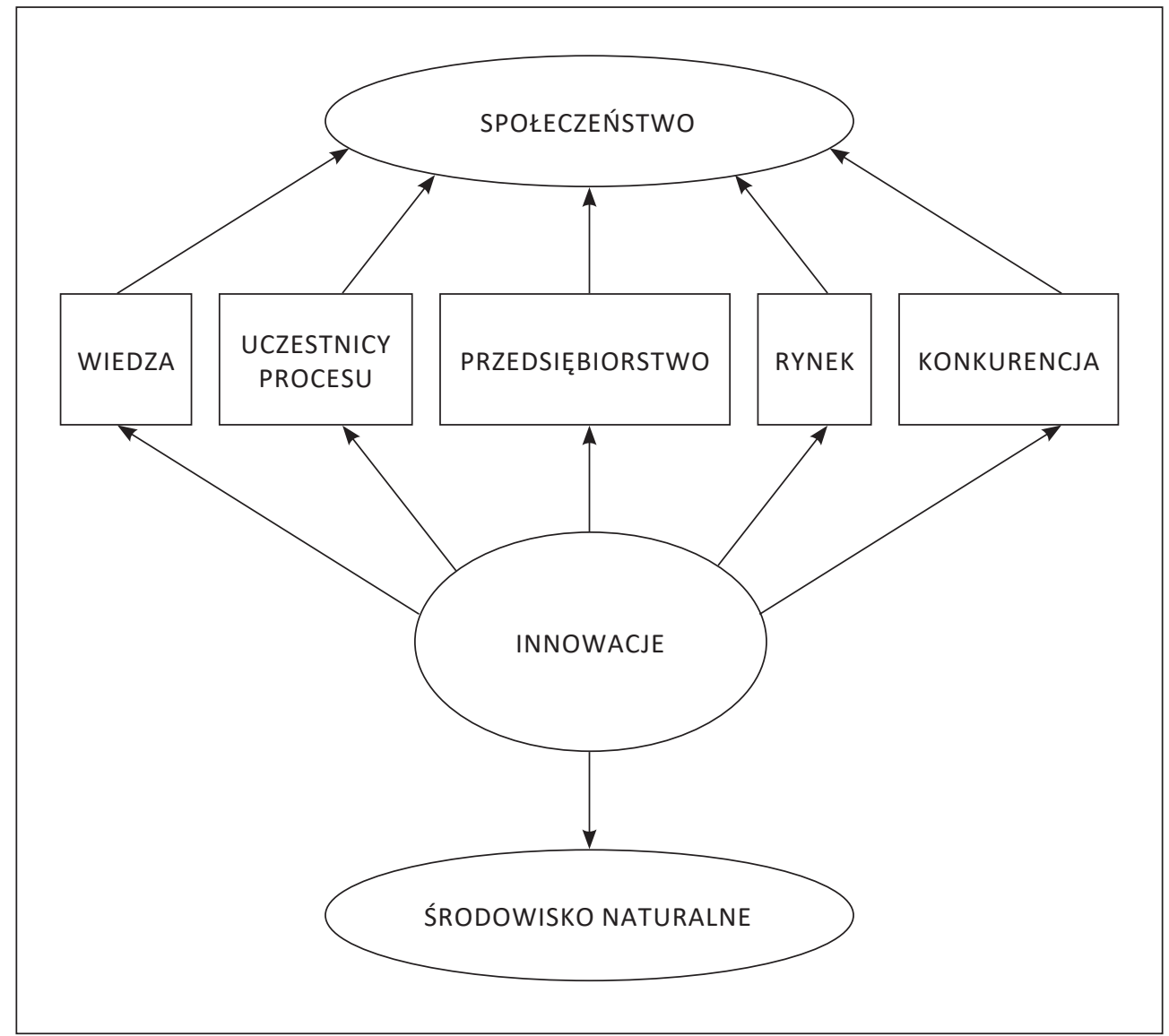

Źródło: Bielski (2000) 
Sektor małych i średnich przedsiębiorstw w Polsce coraz śmielej inwestuje w innowacje, jednak w porównaniu z dużymi przedsiębiorstwami aktywność działań innowacyjnych jest zbyt mała (rycina 2).

Rycina 2. Działalność innowacyjna przedsiębiorstw w latach 2013-2015 - według liczby pracowników w nich zatrudnionych

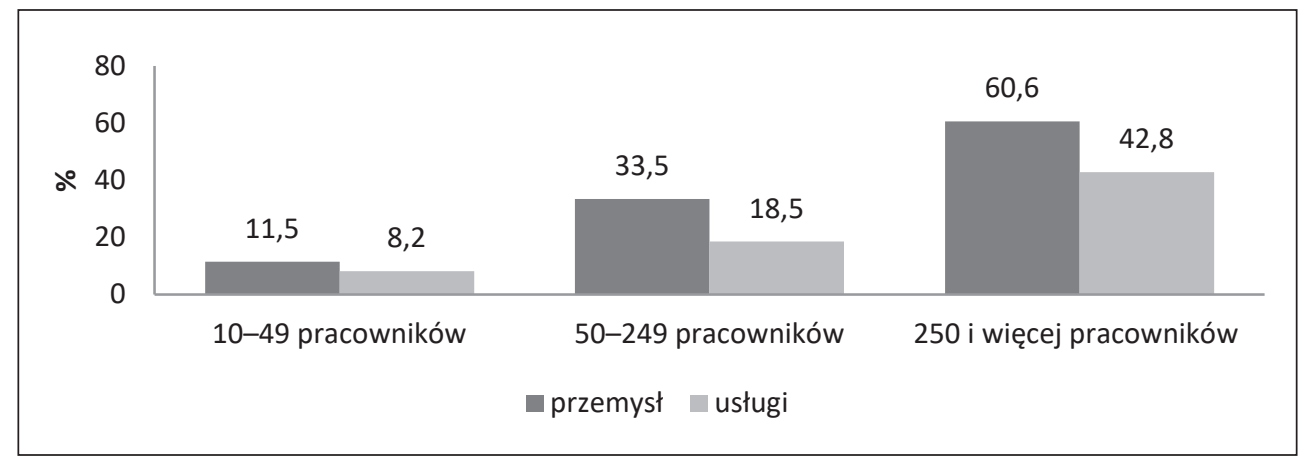

Źródło: GUS (2016)

Porównując raport 2012-2014 z raportem 2013-2015, możemy zauważyć, że działania innowacyjne zdecydowanie częściej podejmują przedsiębiorstwa przemysłowe niż usługowe.

Rycina 3. Działalność innowacyjna przedsiębiorstw w latach 2012-2014 - według liczby pracowników w nich zatrudnionych

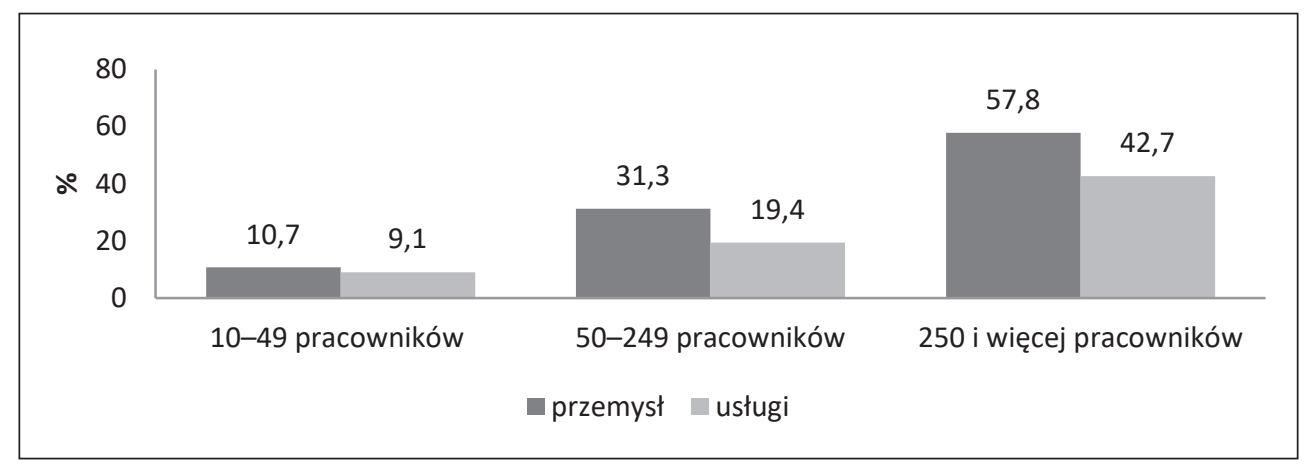

Źródło: GUS (2015)

W latach 2013-2015 w porównaniu z okresem 2012-2014 w przedsiębiorstwach przemysłowych odnotowano wzrost udziału przedsiębiorstw aktywnych innowacyjnie (z 18,6\% do 18,9\%). W usługach wskaźnik ten zmniejszył się o 1,7 p.p. (z 12,3\% do 10,6\%) (GUS, 2016). Odmienny charakter klasyfikacji innowacji działalności produkcyjnych od usługowych świadczy o dysproporcjach związanych z określeniem innowacji. Przedsiębiorstwa produkcyjne mogą być klasyfikowane jako aktywne innowacyjnie przez zakup nowych maszyn, urządzeń, środków transportowych, narzędzi, przyrządów, wyposażenia, podejmowanie działań marketingowych, implementacje nowych procesów oraz wprowadzanie na rynek nowych produktów. Aktywność innowacyjna 
przedsiębiorstw usługowych jest skorelowana z inną ich formą własności, wielkości i branżą. Innowacje w zakresie usług wdrażają częściej podmioty należące do sektora publicznego, zatrudniające wykwalifikowany personel oraz prowadzące działalność, w której rozwój technologii informacyjno-komunikacyjnej ułatwia absorpcję wiedzy i wzmacnia potencjał innowacyjny (Czubała, 2015: 41-44).

Rycina 4. Innowacje przemysłowe w przedsiębiorstwach w latach 2012-2014 i 2013-2015 według podziału NACE

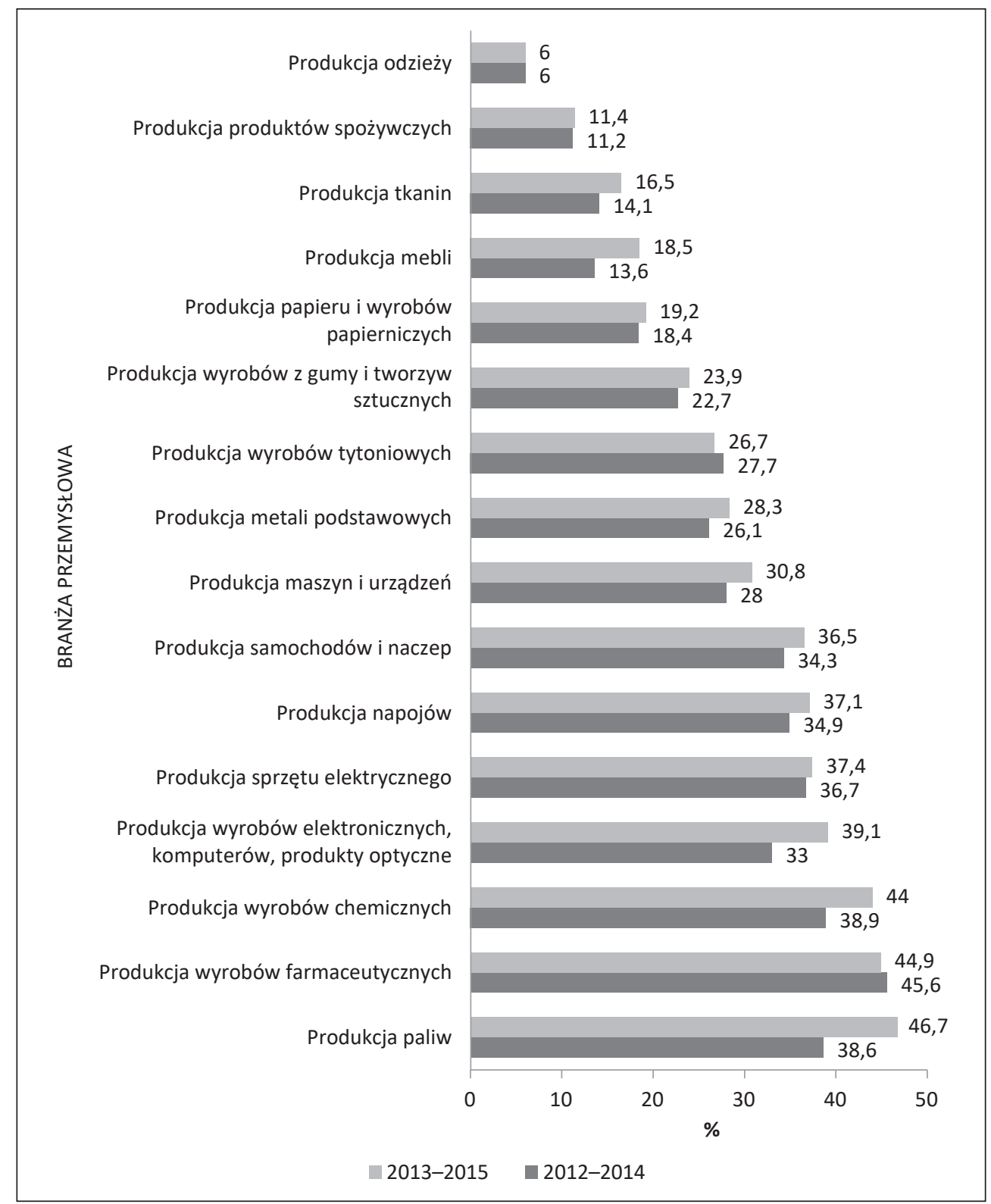

Źródło: opracowanie własne na podstawie danych GUS (2015, 2016) 
Rycina 5. Innowacje usługowe w przedsiębiorstwach w latach 2012-2014 i 2013-2015 według podziału NACE

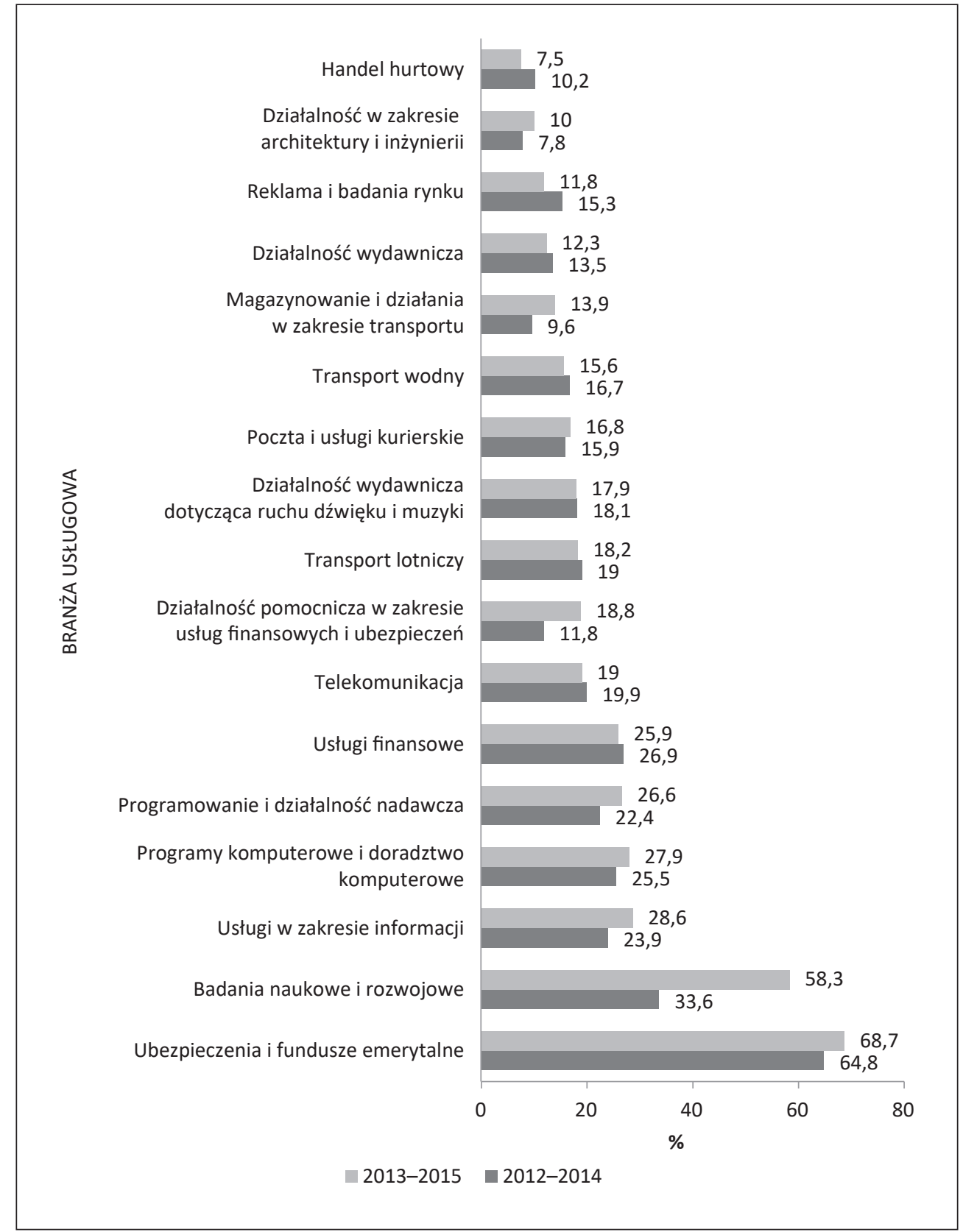

Źródło: opracowanie własne na podstawie danych GUS $(2015,2016)$

Warto zwrócić uwagę na branże, w których przedsiębiorstwa podejmują aktywne innowacje. Według GUS aktywnie innowacyjnym możemy określić przedsiębiorstwo, które wdrożyło przynajmniej jedną innowację produktową lub procesową bądź 
prowadziło działalność innowacyjną zaniechaną lub niezakończoną (w tym działalność badawczo-rozwojową, która nie jest bezpośrednio związana z tworzeniem konkretnej innowacji). W większości z nich to przedsiębiorstwa MŚP działają i rozwijają innowacje. Z perspektywy lat możemy zauważyć całościowo, że więcej branż nieustannie rozwija się za sprawą wdrażania innowacji.

\section{INNOWACYJNOŚĆ GOSPODARKI POLSKIEJ W UJĘCIU WOJEWÓDZTW ORAZ NA TLE WYBRANYCH KRAJÓW UNII EUROPEJSKIEJ}

Innowacyjność rozwija się nie tylko w skali całego kraju, ale również na poziomie regionalnym. Istotną rolę w procesie budowy zdolności innowacyjnych danych regionów w Polsce odgrywa polityka regionalna. Władze w tym zakresie pełnią funkcje wspomagające, koordynujące działania proinnowacyjne podejmowane w regionie (Nowakowska, 2009: 8). Innowacyjność regionów jest wypadkową wielu procesów i zjawisk o charakterze społeczno-gospodarczo-przestrzennym. Jest pochodną działań innowacyjnych podmiotów gospodarczych, sektora naukowo-badawczego, kapitału ludzkiego i społecznego czy samej polityki innowacyjnej (Nowakowska, 2009: 11-14).

Polska w ostatnich latach osiągnęła niewątpliwy sukces, podwajając produkt krajowy brutto (PKB) na mieszkańca od czasu transformacji, co przełożyło się na poprawę poziomu życia. Jednak aby wzrost mógł dalej trwać, ważna jest innowacyjność wszystkich regionów w Polsce. W czołówce województw o największym potencjale innowacyjności utrzymują się niezmiennie cztery województwa: mazowieckie, małopolskie, dolnośląskie oraz pomorskie. Są to regiony, w których dominującą rolę odgrywa aglomeracja miejska: warszawska, krakowska, wrocławska i trójmiejska. Ewidentny sukces tych miejsc tkwi w umiejętności przyciągania najzdolniejszych, najbardziej kreatywnych jednostek, a także ogromnych rynków zbytu. Dobrze rozwinięta oferta edukacyjna przyciąga ludzi, którzy w przyszłości mogą stanowić pożądany kapitał ludzki, a odpowiednia współpraca biznesu z nauką - kapitał finansowy (Indeks Millenium, 2017: 8-10).

W ostatnim czasie możemy dostrzec zmniejszenie dystansu w indeksie innowacyjności między województwem mazowieckim a pozostałymi trzema regionami. Województwo małopolskie, dolnośląskie i pomorskie zwiększają wydatki na badania i rozwój $(B+R)$ w przeliczeniu na PKB. Przyczynami tego wzrostu mogą być m.in. rozwój przemysłu innowacyjnego, infrastruktury edukacyjnej i transportowej, działania stref ekonomicznych. Dystans między województwami zmniejsza się, a różnice w potencjale innowacyjnym między regionami są coraz mniejsze (Indeks Millenium, 20017: 10-12). Na dominujące regiony powinny zwrócić uwagę województwa, które są na ostatnich miejscach w zestawieniach. Na niską pozycję wpływa wiele czynników, m.in. niski nakład na B+R, niska wydajność pracy, stopa wartości dodanej, a także niewielu studentów i mało przyznawanych patentów (Zadura-Lichota, 2015: 73-80).

Na rycinie 6 została przedstawiona mapa Polski, która uwzględnia wszystkie województwa, ukazując jednocześnie podejmowane aktywności innowacyjne w roku 2017. Rycina 7 przedstawia porównanie względem 2016 i 2017 roku. Województwa w rankingu Indeks Millennium 2017 Potencjał innowacyjności regionów (Indeks Millenium, 2017) zostały ocenione pod względem składowych, takich jak wydajność pracy, stopa wartości dodatniej, wydatki na $\mathrm{B}+\mathrm{R}$, edukacja policealna, pracujący w B+R oraz liczba patentów. Województwa zostały ocenione w skali od 1 do 100. 
Rycina 6. Ranking województw podejmujących aktywność innowacyjną



Źródło: Indeks Millennium (2017)

Rycina 7. Porównanie wyników województw w Indeksie Millennium w latach 2016 i 2017

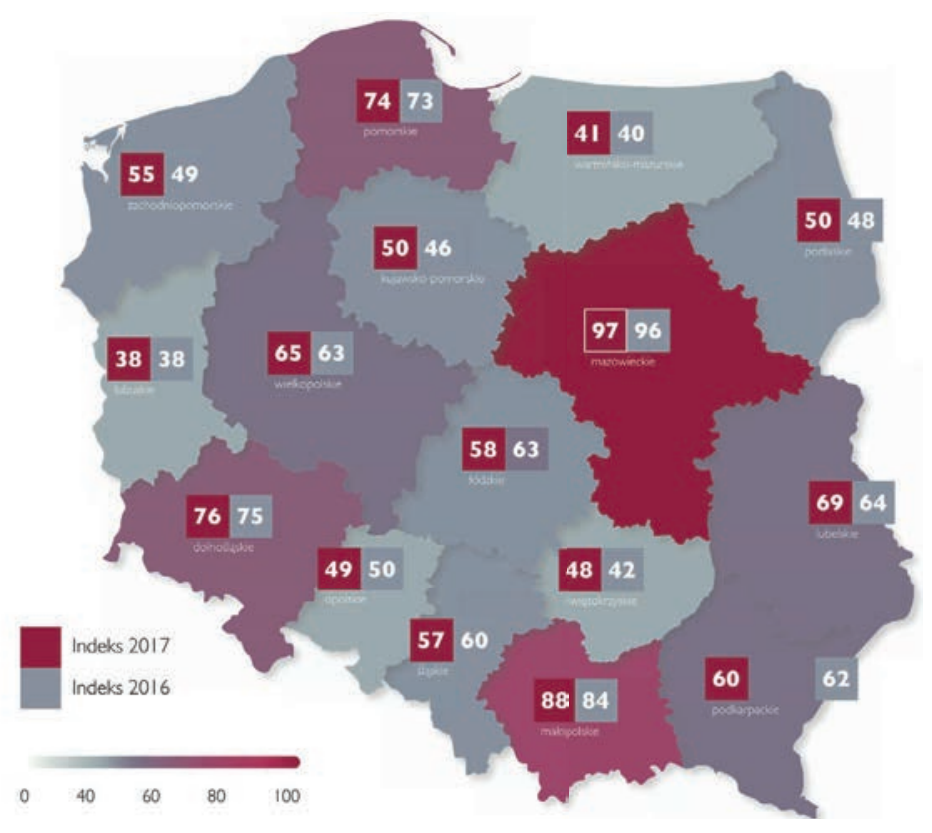

Źródło: Indeks Millennium (2017) 
W tabeli 1 została przedstawiona analiza zmiany wyników województw z perspektywy lat 2010-2015. Zauważalny największy rozwój potencjału innowacyjnego osiągnęło województwo lubelskie. Z miejsca 8 awansowało na miejsce 5 i konsekwentnie utrzymuje tę pozycję. Niewiele gorszy wynik osiągnęły województwa podkarpackie oraz kujawsko pomorskie. Jedną z głównych przyczyn awansu województwa lubelskiego była liczba patentów na 1 mln mieszkańców, która wzrosła z 2010 do 2015. Zwiększona liczba patentów jest konsekwencją dobrej pozycji Lublina jako ośrodka akademickiego (Indeks Millenium, 2017: 11-12).

Tabela 1. Porównanie potencjału innowacyjności regionów za lata 2010-2015 według raportu Indeks Millenium

\begin{tabular}{|l|c|c|c|c|c|c|c|c|c|c|c|c|}
\hline \multirow{2}{*}{\multicolumn{1}{|c}{ Województwo }} & \multicolumn{9}{|c|}{ Liczba punktów } & \multicolumn{6}{c|}{ Miejsce } \\
\cline { 2 - 14 } & 2010 & 2011 & 2012 & 2013 & 2014 & 2015 & 2010 & 2011 & 2012 & 2013 & 2014 & 2015 \\
\hline Mazowieckie & 97 & 92 & 92 & 91 & 96 & 97 & 1 & 1 & 1 & 1 & 1 & 1 \\
\hline Małopolskie & 80 & 76 & 80 & 78 & 84 & 88 & 2 & 2 & 2 & 2 & 2 & 2 \\
\hline Dolnośląskie & 68 & 74 & 77 & 74 & 75 & 76 & 4 & 3 & 3 & 3 & 3 & 3 \\
\hline Pomorskie & 68 & 68 & 74 & 70 & 73 & 74 & 3 & 4 & 4 & 4 & 4 & 4 \\
\hline Lubelskie & 57 & 59 & 63 & 56 & 64 & 69 & 8 & 8 & 6 & 9 & 5 & 5 \\
\hline Wielkopolskie & 60 & 60 & 64 & 60 & 63 & 65 & 7 & 6 & 5 & 5 & 7 & 6 \\
\hline Podkarpackie & 54 & 52 & 55 & 58 & 62 & 60 & 9 & 10 & 9 & 7 & 8 & 7 \\
\hline Łódzkie & 61 & 60 & 61 & 60 & 63 & 58 & 5 & 7 & 7 & 6 & 6 & 8 \\
\hline Śląskie & 61 & 61 & 57 & 56 & 60 & 57 & 6 & 5 & 8 & 8 & 9 & 9 \\
\hline Zachodniopomorskie & 47 & 51 & 52 & 49 & 49 & 55 & 11 & 11 & 11 & 10 & 11 & 10 \\
\hline Podlaskie & 48 & 45 & 46 & 48 & 48 & 50 & 10 & 14 & 13 & 11 & 12 & 11 \\
\hline Kujawsko-pomorskie & 46 & 48 & 48 & 46 & 46 & 50 & 14 & 12 & 12 & 12 & 13 & 12 \\
\hline Opolskie & 47 & 52 & 53 & 46 & 50 & 49 & 12 & 9 & 10 & 13 & 10 & 13 \\
\hline Świętokrzyskie & 46 & 45 & 42 & 40 & 42 & 48 & 13 & 13 & 15 & 15 & 14 & 14 \\
\hline Warmińsko-mazurskie & 43 & 41 & 42 & 41 & 40 & 41 & 15 & 15 & 14 & 14 & 15 & 15 \\
\hline Lubuskie & 34 & 35 & 34 & 35 & 38 & 38 & 16 & 16 & 16 & 16 & 16 & 16 \\
\hline
\end{tabular}

Źródło: Indeks Millennium (2017)

Różnice w działalności innowacyjnej między województwami występują, są zauważalne dysproporcje między nimi. Te różnice można również dostrzec na arenie europejskiej. Poszczególne kraje Unii Europejskiej sukcesywnie starają się zmniejszyć lukę technologiczną, która we współczesnej gospodarce globalnej nie ma charakteru procesu liniowego, a w dużej mierze jest zależna od struktury gospodarki (Kubielas, 2009: 211). Zmiany struktury gospodarczej to zmiany związane z długimi przedziałami czasowymi, w których główną rolę zaczyna odgrywać wysoka technologia. Na arenie europejskiej i globalnej technologia staje się najważniejszym towarem w wymianie międzynarodowej i budowie pozycji konkurencyjnej (Drabińska, 2012: 10).

Innowacyjność poszczególnych gospodarek jest mierzona według różnych kryteriów. Polska od wielu lat zajmuje relatywnie odległe miejsce w rankingach. Odzwierciedla to stan, w którym przedsiębiorstwa zbyt mało inwestują w aktywność innowacyjną. Polska oceniana jest jako kraj, który znajduje się w początkowym stadium procesu rozwoju innowacyjności wśród państw UE. Przyczyn tego jest wiele, niemniej warto wskazać, iż nieodpowiednio realizowana polityka państwa, która w zbyt małym stopniu wspomaga rozwój innowacyjności, w tym przedsiębiorstw MŚP, może przyczynić 
Rycina 8. Innowacyjność UE 2016

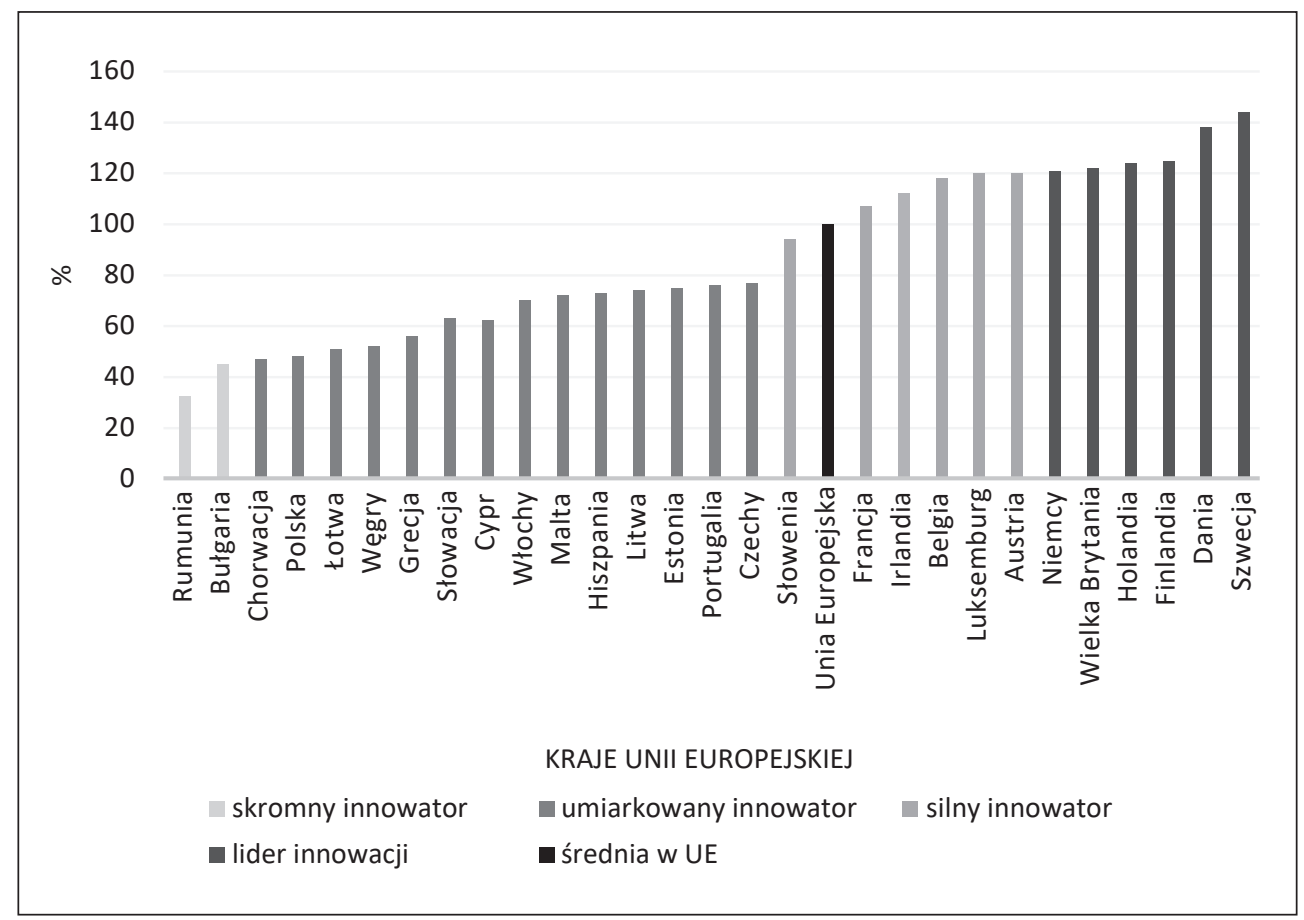

Źródło: European Innovation... (2019)

się do zbyt małej aktywności innowacyjnej. Wzrost innowacyjny polskiej gospodarki powinien być priorytetem w polityce i strategii państwa. Strategie innowacyjne powinny być realizowane z należną konsekwencją, rzetelnością rozwiązywania problemów, które związane są ze zbyt niskim poziomem działalności innowacyjnej podejmowanym przez przedsiębiorstwa w sektorze MŚP (Siuta-Tokarska, Borowiecki, 2017: 163-164).

Liderem innowacyjności w Unii Europejskiej jest Szwecja, a za nią uplasowały się: Dania, Finlandia, Holandia i Wielka Brytania. Polska zajmuje czwarte miejsce od końca. Nakłady na działania innowacyjne sektora MŚP są zbyt niskie. W tabeli 2 porównano polski sektor MŚP w stosunku do innych krajów UE według poziomu techniki wśród przedsiębiorstw przemysłowych oraz wykorzystania wiedzy wśród przedsiębiorstw usługowych, z wyróżnieniem podmiotów zaawansowanych technologicznie. Można w związku z tym wyodrębnić następujące sektory mikro-, małych i średnich przedsiębiorstw:

- produkcja,

- budownictwo,

- hurt,

- zakwaterowanie i wyżywienie,

- usługi biznesowe,

- inne sektory.

Przedstawione w tabeli 2 dane świadczą o stosunkowo niskich udziałach przedsiębiorstw MŚP w Polsce w działaniach innowacyjnych. 


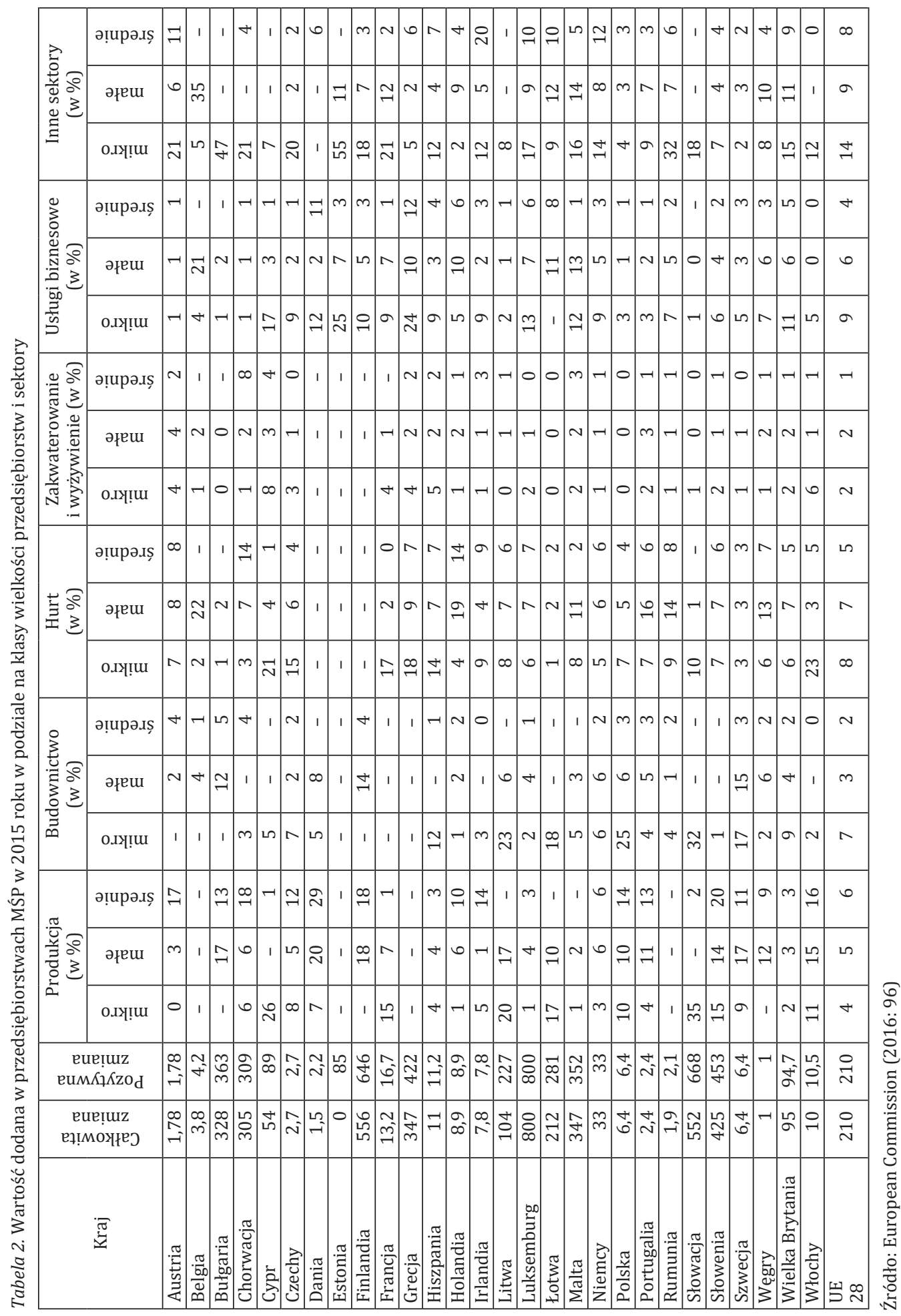


Wyniki przedstawione w tabeli 2 wskazują na potrzebę ilościowego i jakościowego rozwoju mikro-, małych i średnich podmiotów. Ma to przełożenie na możliwość ich konkurowania na rynkach zagranicznych. Z perspektywy gospodarki Polski pobudza wzrost efektywności i rozwoju. W przypadku naszej gospodarki, która zaliczana jest do mniej zaawansowanych technologicznie, duże znaczenie ma prowadzenie odpowiedniej polityki państwa, w tym ograniczenie barier działalności dla przedsiębiorstw podejmujących działania innowacyjne oraz nakładów na rozwój tych działań. Ważne jest tworzenie warunków o charakterze prorozwojowym dla pozostałych podmiotów MŚP. Zapewnienie odpowiednich warunków i nakładów umożliwi sektorowi MŚP inwestycje w wysokie technologie jednocześnie zwiększy liczbę podejmowanych inicjatyw innowacyjnych (Siuta-Tokarska, 2017: 250-253).

\section{FINANSOWANIE INNOWACJI PRZEDSIĘBIORSTW MŚP W POLSCE I UNII EUROPEJSKIEJ}

Współczesne innowacje postrzegane są m.in. jako efekt, rezultat współpracy między instytucjami naukowymi a działalnością gospodarczą. Innowacja zatem to wdrażanie w praktykę gospodarczą nowego lub udoskonalonego produktu, usługi, procesu, nowej metody organizacyjnej lub marketingowej (Bukowski, Szpor, Śniegocki, 2012: 3). Aby było możliwe podjęcie działań innowacyjnych, niezbędny jest kapitał finansowy, który jest fundamentalnym czynnikiem. Innowacje mogą być finansowane przez instrumenty publiczne (instytucje publiczne), a także przez instrumenty rynkowe (banki, giełda) (Zembura, 2016: 110).

Do grupy publicznych instrumentów możemy zaliczyć dotacje przyznane na lata 2014-2020, wśród których najpopularniejsze są (Komisja Europejska, 2014):

a) programy operacyjne finansowane z funduszy unijnych i budżetu państwa:

- Inteligentny rozwój,

- Wiedza-Edukacja-Rozwój,

- Polska Wschodnia (dotyczy pięciu województw: warmińsko-mazurskiego, świętokrzyskiego, podlaskiego, podkarpackiego, lubelskiego),

b) inicjatywa flagowa w ramach strategii Europa 2020, Unia innowacyjna,

c) regionalne programy operacyjne na lata 2014-2020,

d) europejski fundusz kapitału podwyższonego ryzyka,

e) program na rzecz konkurencyjności przedsiębiorstw małych i średnich przedsiębiorstw, (COME).

Do instrumentów rynkowych możemy zaliczyć:

3. instrumenty kapitałowe, wśród których najpopularniejsze to:

a) instrumenty giełdowe (NewConnect, GPW),

b) instrumenty pozagiełdowe (buissnes angels, seed fund, venture capital, erivate equity);

4. instrumenty dłużne, do których należą:

a) obligacje (Catalyst, GPW),

b) pożyczki,

c) kredyty,

d) leasing.

Każde państwo nieustannie dąży do podnoszenia swojej konkurencyjności, czego nieodłącznym elementem jest wdrażanie innowacji. Dlatego też tak istotną kwestią jest sposób finansowania innowacji. Państwa Unii Europejskiej, aby wspierać działalność 
innowacyjną sektora MŚP, stosują kompleksowe programy finansowania (dotacje, ulgi podatkowe, pożyczki itp.). Działalność innowacyjna jest wspierana przez państwo w zasięgu regionalnym, krajowym czy nawet międzynarodowym. Państwa decydują się na udzielanie dotacji rządowych na badania i rozwój nie tylko nowo powstałym przedsiębiorstwom, ale również już istniejącym podmiotom, które chcą się rozwijać (Ciborowski, 2014: 66).

Z analizy danych dotyczących nakładów na działalność badawczo-rozwojową w Polsce wynika, że ich wartość wyraźnie zwiększyła się z 2 mld zł w 1995 roku, do 9 mld zł w 2009 roku i ponad 18 mld w 2015 roku (wzrost o 100\% w latach 20092015). Jednak w ujęciu wskaźnikowym jest to jeden z najniższych poziomów finansowania w krajach Unii Europejskiej. W1995 roku wyniósł 0,63\% PKB, w 2015 roku 1\% PKB przy średniej krajów Unii Europejskiej wynoszącej 2,03\% PKB (Siuta-Tokarska, Borowiecki, 2017: 170-171).

Rycina 9. Wydatki brutto państw UE na działalność badawczo-rozwojową w 2015 roku

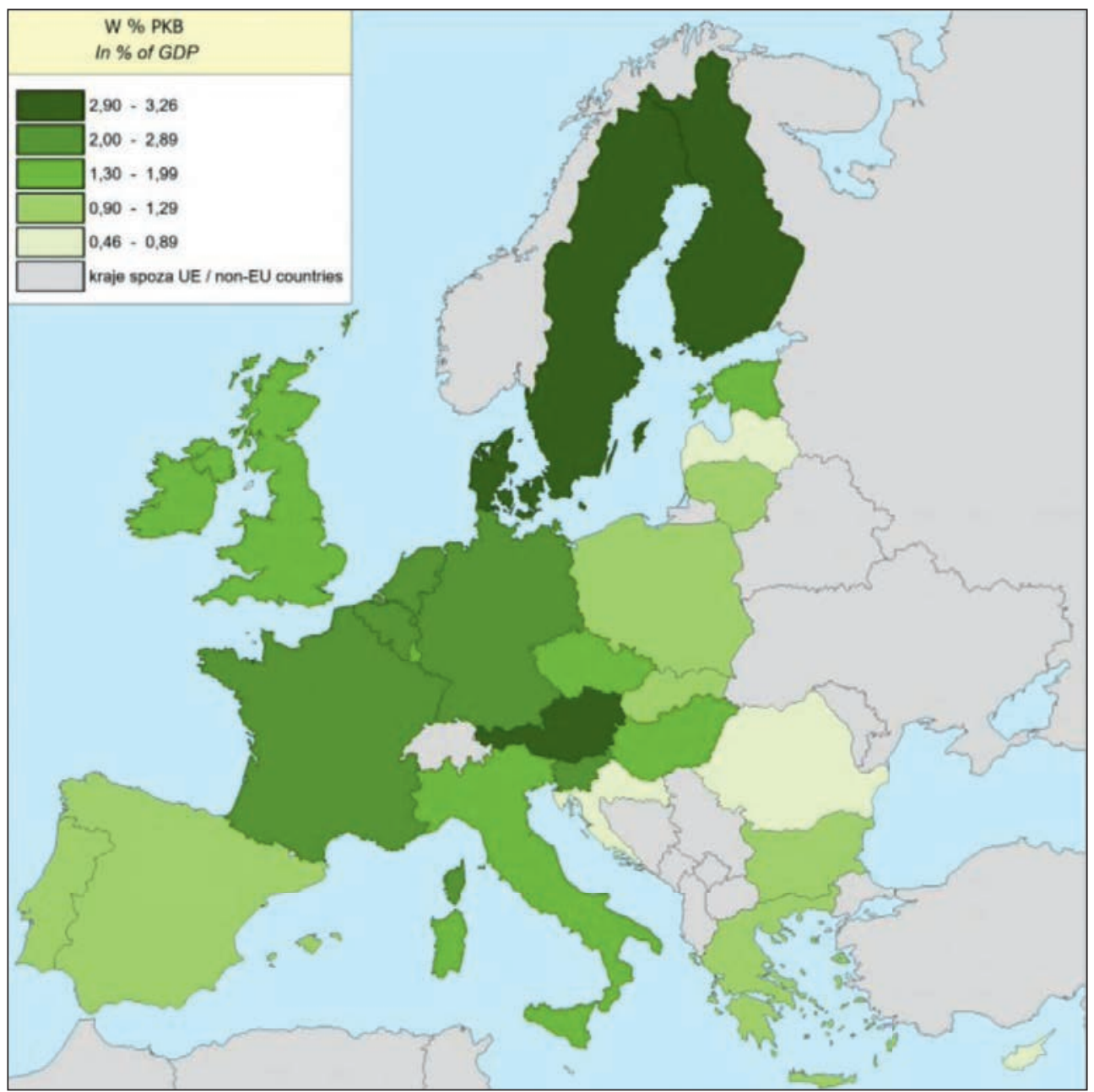

Źródło: Eurostat (2016) 
Zbyt niskie nakłady na działalność innowacyjną przedsiębiorstw oraz nieefektywnie prowadzona polityka innowacji Polski skutkują niską pozycją w rankingach w stosunku do innych krajów Unii Europejskiej. Poprawa sytuacji wymaga podjęcia konkretnych decyzji na szczeblu rządowym. W szczególności chodzi o wspieranie i finansowanie podmiotów zajmujących się działalnością przemysłową, które byłyby zdolne do samodzielnego prowadzenia prac badawczo-rozwojowych. Ważne jest wsparcie również dla podmiotów, które będą w stanie rozwijać działalność innowacyjną niezależnie od otoczenia proinnowacyjnego, oraz zajmujących się prowadzeniem badań i prac rozwojowych kończących się praktycznymi rezultatami w postaci innowacji produktowych, nowych technologii, nowych usług czy nowoczesnych rozwiązań w zakresie organizacji i zarządzania (Siuta-Tokarska, Borowiecki, 2017: 170-171).

\section{BARIERY WYNIKAJĄCE Z PODJĘCIA PROCESÓW INNOWACYJNYCH W MAŁYCH I ŚREDNICH PRZEDSIĘBIORSTWACH W POLSCE}

Bariery rozwoju działalności innowacyjnej przedsiębiorstw sektora MŚP są szeroko rozumiane. Każdy czynnik hamujący wzrost i rozwój innowacyjności przedsiębiorstwa może być zaliczony do ograniczeń.

Literatura przedmiotu wymienia kilka różnorodnych klasyfikacji barier, które wpływają na funkcjonowanie przedsiębiorstw i podejmowanie przez nie działalności innowacyjnej. Jedna z klasyfikacji przyjmuje za kryterium podział czasu występowania i określa dwa rodzaje barier (Skowronek-Mielczarek, Bojewska, 2017: 48-49):

1. bariery wejścia: występują w momencie powstania koncepcji innowacji oraz uruchamiania jej w działalności przedsiębiorstwa i obejmują np. bariery psychologiczne właściciela związane z podjęciem decyzji o wprowadzeniu procesu innowacyjnego, ograniczone zasoby kapitału na realizacje innowacji, brak dostępu do wykwalifikowanej kadry zajmującej się innowacjami, ograniczona znajomość i niejasność przepisów związanych ze wspieraniem innowacji, często niedostrzeganie okazji rynkowych lub ich przewartościowanie,

2. bariery rozwoju: nieodpowiednia kolejność wdrożenia innowacji w przedsiębiorstwie wynikająca z różnego zapotrzebowania przedsiębiorstwa na kapitał finansowy, ludzki, rzeczowy, informacyjny w poszczególnych fazach procesu zarządzania innowacją.

W literaturze można również spotkać inny podział barier wpływających na funkcjonowanie przedsiębiorstw i ich działalność innowacyjną, wyróżniony ze względu na kryterium miejsca ich występowania. Są to (Łobejko, Pierścionek, 2011: 202):

1. bariery zewnętrzne: wynikające z sytuacji na rynku, poziomu popytu i podaży, sytuacji ekonomicznej, demograficznej, polityki rządu i władz lokalnych,

2. bariery wewnętrzne: mające źródło w przedsiębiorstwie, są związane z osobą właściciela-menedżera i prowadzoną przez niego strategią zarządzania innowacją oraz dysponowania posiadanymi zasobami.

Trzeba zauważyć, że struktura barier wewnętrznych opisanych w tabeli 3 może być zmienna w czasie, siła ich oddziaływań na konkretne przedsiębiorstwo może być odmienna. Bariery wewnętrzne z barierami zewnętrznymi tworzą zbiór uwarunkowań, które mogą zablokować aktywność innowacyjną przedsiębiorstw sektora MŚP. 
Tabela 3. Bariery wewnętrzne wpływające na podjęcie działalności innowacyjnej

\begin{tabular}{|l|l|}
\hline \multicolumn{2}{|c|}{ Bariery wewnętrzne } \\
\hline $\begin{array}{l}\text { Cele osobowościowe } \\
\text { menedżerów }\end{array}$ & $\begin{array}{l}\text { Psychologiczne, społeczne, związane z właścicielem, poziomem kompetencji } \\
\text { menedżerskich, doświadczeniem i umiejętnością prowadzenia biznesu }\end{array}$ \\
\hline $\begin{array}{l}\text { Zarządzanie } \\
\text { procesami }\end{array}$ & $\begin{array}{l}\text { Koncentracja na bieżących operacjach biznesowych, ograniczona sprawność } \\
\text { zarządzania, brak profesjonalizmu }\end{array}$ \\
\hline Kadra zarządzająca & Brak kwalifikacji, świadomości dotyczącej wykorzystania innowacji w biznesie \\
\hline $\begin{array}{l}\text { Zasoby } \\
\text { przedsiębiorstwa }\end{array}$ & $\begin{array}{l}\text { Brak odpowiedniej konfiguracji zasobów, odpowiedniego ich wykorzystania, } \\
\text { optymalizacji zasobów w różnych fazach wdrażania }\end{array}$ \\
\hline $\begin{array}{l}\text { Forma prawna } \\
\text { przedsiębiorstwa }\end{array}$ & $\begin{array}{l}\text { W sektorze MŚP w Polsce dominuje działalność jednoosobowa, takie firmy } \\
\text { mają mniejszy dostęp do kapitału niż np. spółki kapitałowe, które mają większą } \\
\text { możliwość uzyskania środków finansowych z zewnętrznych źródeł, np. z rynku } \\
\text { kapitałowego }\end{array}$ \\
\hline $\begin{array}{l}\text { Ograniczenia } \\
\text { finansowe } \\
\text { przedsiębiorstwa }\end{array}$ & $\begin{array}{l}\text { Stanowią istotne uwarunkowanie wewnętrznego rozwoju. Środki na innowacje } \\
\text { MŚP pochodzą ze środków własnych, a nie zewnętrznych - w fazie rozpoczynania } \\
\text { działalności innowacyjnej. W fazie wzrostu innowacji środki pochodzą z nadwyżek } \\
\text { finansowych, a nie z pozyskanych środków zewnętrznych }\end{array}$ \\
\hline $\begin{array}{l}\text { Utrzymanie poziomu } \\
\text { finansów }\end{array}$ & $\begin{array}{l}\text { Niski poziom akumulacji finansów, wysokie koszty funkcjonowania } \\
\text { przedsiębiorstwa, niski poziom rentowności, brak obiektywnej oceny kondycji } \\
\text { finansowej przedsiębiorstwa, która jest podstawą do uzyskania kapitału } \\
\text { finansowego pochodzącego ze źródeł zewnętrznych }\end{array}$ \\
\hline
\end{tabular}

Źródło: opracowanie własne na podstawie Skowronek-Mielczarek (2016: 48-51)

Tabela 4. Bariery zewnętrzne wpływające na podjęcie działalności innowacyjnej

\begin{tabular}{|l|l|}
\hline \multicolumn{2}{|c|}{ Bariery zewnętrzne } \\
\hline Rynkowe & $\begin{array}{l}\text { Niekorzystne zjawiska zachodzące na rynku, silny nacisk konkurencji, niski } \\
\text { poziom ochrony przed nieuczciwą konkurencją }\end{array}$ \\
\hline Prawno-podatkowe & $\begin{array}{l}\text { Związane z dużą liczbą i zmiennością regulacji prawnych: prawa podatkowego, } \\
\text { prawa pracy. Długotrwałe procedury administracyjne, nie dość sprawne } \\
\text { funkcjonowanie instytucji, rozwiązań prawnych i programów wspierających } \\
\text { innowacyjność przedsiębiorstw }\end{array}$ \\
\hline Finansowe & $\begin{array}{l}\text { Koszty pozyskania rozwiązań innowacyjnych, czasochłonne i skomplikowane } \\
\text { procedury, skomplikowane warunki ubiegania się o wsparcie publiczne, mały } \\
\text { poziom wydatków budżetu państwa na badania i rozwój }\end{array}$ \\
\hline Społeczne & $\begin{array}{l}\text { Trudności w pozyskaniu wykwalifikowanej kadry, która ma doświadczenie } \\
\text { w działaniach innowacyjnych, ograniczanie kosztów osobowych }\end{array}$ \\
\hline $\begin{array}{l}\text { Innowacyjno- } \\
\text {-technologiczne }\end{array}$ & $\begin{array}{l}\text { Niska skłonność do wdrażania innowacji w mniejszych przedsiębiorstwach, niski } \\
\text { poziom ulg i zachęt ekonomicznych do podejmowania działalności innowacyjnej } \\
\text { i wdrażania innowacji }\end{array}$ \\
\hline Informacyjne & $\begin{array}{l}\text { Techniczne, finansowe, organizacyjne problemy w dostępie do informacji } \\
\text { o innowacyjnych rozwiązaniach: poziomu dostępu do internetu; poziomu rozwoju } \\
\text { edukacji biznesowej; ograniczony dostęp do przedsiębiorstw, które świadczą } \\
\text { usługi związane z dyfuzją innowacji }\end{array}$ \\
\hline
\end{tabular}

Źródło: opracowanie własne na podstawie Friszt (2013: 70), Bojewska (2015: 123)

Rodzaje barier wpływają na działalność innowacyjną przedsiębiorstw. Może być też ona identyfikowana z otoczeniem, na które wpływa. Można zatem mówić o otoczeniu, na które bariery wpływają globalne, konkurencyjne i regionalne. Największy wpływ na powstanie barier ma otoczenie globalne, ponieważ trendy i zjawiska w nim zachodzące wywołują zmiany w otoczeniu konkurencyjnym i regionalnym (Skowronek-Mielczarek. 2015: 252). Do największych problemów w działalności innowacyjnej w Polsce należą (Siuta-Tokarska, Borowiecki, 2017: 169-170): 
- niski poziom wykorzystania potencjału innowacji odnoszący się do nauki polskiej,

- problemy w sferze edukacji, związane m.in. z częstym kształceniem ogólnych niż zawodowym, jak również niedostosowaniem programów kształcenia do wymogów nowoczesnej gospodarki,

- niski poziom innowacji w agendzie publicznej,

- niewielka zdolność przedsiębiorstwa do generowania innowacji oraz dominujący imitacyjny paradygmat rozwoju przedsiębiorstw,

- problemy dotyczące dostępności zewnętrznych źródeł finansowania działalności innowacyjnej w przedsiębiorstwach sektora MŚP,

- niski poziom wydatków na działalność B+R w całej gospodarce,

- występowanie luki innowacyjnej w zakresie wydatków sektora prywatnego na innowacje,

- niewystarczający stopień zachęt i ułatwień w prowadzeniu działalności innowacyjnej dla przedsiębiorstw przy istniejących narzędziach polityki publicznej,

- przyciąganie bezpośrednich inwestycji zagranicznych o stosunkowo niskim udziale prac rozwojowych,

- inne.

Kluczem do osiągnięcia sukcesu rynkowego, oprócz rywalizacji, prowadzenia walki konkurencyjnej, może być kooperacja i współdziałanie. Dlatego istotne jest, aby przedsiębiorstwa sektora MŚP miały odpowiednie warunki do podejmowania współpracy, tworzenia i wdrażania innowacji do praktyki gospodarczej. Szczególnie ważne jest ograniczenie barier, które tworzą warunki niepewności w funkcjonowaniu i rozwoju przedsiębiorstw.

\section{WNIOSKI KOŃCOWE}

We współczesnej gospodarce nieustannie rośnie znaczenie innowacji. Coraz większe znaczenie ma poziom innowacyjności mikro-, małych i średnich przedsiębiorstw. Mogą one podejmować działania innowacyjne w momencie, gdy państwo zagwarantuje im odpowiednie warunki, które sprzyjają podejmowaniu tego typu inicjatyw.

Należy zwrócić uwagę na to, że przedsiębiorstwa sektora MŚP coraz częściej podejmują działania innowacyjne (szczególnie produktowe), czego efektem jest zwiększenie zysków oraz wzrost zatrudnienia. Źródeł działań innowacyjnych upatrywać należy w klientach oraz w konkurencji. Największą barierę dla wprowadzania innowacji w sektorze MŚP stanowi brak środków finansowych oraz brak wsparcia ze strony państwa.

Na innowacyjność danego kraju składa się m.in. innowacyjność sektora MŚP. Innowacyjność polskiej gospodarki jest stosunkowo niska wobec innych krajów Unii Europejskiej. W ciągu kilku lat zauważalny jest tylko nieduży wzrost. Poprawy obecnej pozycji należy upatrywać w czynnikach związanych z unowocześnianiem infrastruktury zarządzania państwem i jego elementów, które mogą oddziaływać na podejmowanie działalności innowacyjnych. Prezentowane wykresy oraz raporty oceniają nisko nowoczesność polskiej gospodarki, w szczególności jej innowacyjność i konkurencyjność.

Wzrost nakładów sektora prywatnego i rządowego na kwestie innowacyjności pozwoli przedsiębiorstwom zbudować lepszą pozycję konkurencyjną na arenie międzynarodowej. Ciągłe wprowadzanie zmian w zakresie ułatwiania prowadzenia działalności gospodarczej, promowania innowacyjności, ułatwianie dostępu do kapitału zewnętrznego oraz ograniczenie złożoności polskiego prawa mogą zagwarantować awans Polski w przyszłości. 


\section{Literatura \\ References}

Bojewska, B. (2015). Innowacyjność organizacji sieciowych $w$ gospodarce opartej na wiedzy. Warszawa: Oficyna Wydawnicza SGH.

Bukowski, M., Szpor, A., Śniegocki, A. (2012). Potencjał i bariery polskiej innowacyjności. Warszawa: Instytut Badań Strukturalnych.

Bielski, I. (2000). Przebieg i uwarunkowania procesów innowacyjnych. Bydgoszcz: Oficyna Wydawnicza Ośrodka Postępu Organizacyjnego sp. z o.o.

Ciborowski, R. (2014). Instrumenty polityki innowacyjnej Unii Europejskiej i ich wpływ na działalność proinnowacyjną przedsiębiorstw. Optimum Studia Ekonomiczne, 6(72), 62-78

Czubała, A. (2015). Innowacje w sektorze usług w Polsce. Tarnów: Małopolska Wyższa Szkoła Ekonomiczna.

Drabińska, D. (2012). Innowacyjność gospodarki w wymiarze współczesnym i w ujęciu historycznym. Kwartalnik Kolegium Ekonomiczno-Społecznego, Prace i Studia, 2, 9-25

European Commision (2016). Annual Report on European SMEs 2015/2016.

European Innovation Scoreboard 2018 (2019, 16 stycznia). Pozyskano z http://www.kpk.gov.pl/ wp-content/uploads/2018/06/ETAY18001ENN_version26062018.pdf

Friszt, D. (2013). Uwarunkowania dyfuzji innowacji w polskiej gospodarce. Warszawa: CeDeWu.

Głuszczuk, D. (2016). Problem pomiaru działalności innowacyjnej przedsiębiorstw na poziomie regionów. Prace Naukowe, 433. Wrocław: Wydawnictwo Uniwersytetu Ekonomicznego we Wrocławiu.

Główny Urząd Statystyczny (2015). Działalność innowacyjna przedsiębiorstw w latach 20122014. Warszawa.

Główny Urząd Statystyczny (2016). Działalność innowacyjna przedsiębiorstw w latach 20132015. Warszawa.

Główny Urząd Statystyczny (2017). Działalność innowacyjna przedsiębiorstw w Polsce w latach 2014-2016. Opracowanie sygnalne. Warszawa.

Indeks Millennium 2017 (2017). Potencjał innowacyjności regionów. Warszawa.

Janasz, W., Kozioł, K. (2007). Determinanty działalności innowacyjnej przedsiębiorstw. Warszawa: Polskie Wydawnictwo Ekonomiczne.

Komisja Europejska (2014). Horyzont 2020. Program ramowy UE w zakresie badań naukowych i innowacji.

Kubielas, S. (2009). Innowacje i luka technologiczna w gospodarce globalnej opartej na wiedzy. Strukturalne i makroekonomiczne uwarunkowania. Warszawa: Wydawnictwo Uniwersytetu Warszawskiego.

Łobejko, S., Pierścionek, Z. (2011). Zarządzanie strategiczne w praktyce polskich przedsiębiorstw. Warszawa: Oficyna Wydawnicza Szkoły Głównej Handlowej.

Mazur-Wierzbicka, E. (2015). Działalność innowacyjna przedsiębiorstw w Polsce. Szczecin: Uniwersytet Szczeciński.

Motyka, S. (2011). Pomiar innowacyjności przedsiębiorstwa. Kraków: Katedra Inżynierii Procesów Produkcyjnych, Politechnika Krakowska.

Nowakowska, A. (2009). Zdolności innowacyjne polskich regionów. Łódź: Wydawnictwo Uniwersytetu Łódzkiego.

Oslo Manual (2005). Gulidelines for collecting and interpreting innovation data. OECD.

Poznańska, K. (2016). Współpraca małych i średnich przedsiębiorstw z podmiotami zewnętrznymi w zakresie innowacyjności. Studia Ekonomiczne. Zeszyty Naukowe Uniwersytetu Ekonomicznego w Katowicach, 280, 143-156.

Siuta-Tokarska, B. (2017). Zaawansowanie technologiczne przedsiębiorstwa sektora MŚP w Polsce. Nierówności Społeczne a Wzrost Gospodarczy, 50(2), 241-255.

Siuta-Tokarska, B., Borowiecki, R. (2017). Problemy innowacyjności gospodarki Polskiej, ze szczególnym uwzględnieniem działalności badawczo-rozwojowej. Nierówności Społeczne a Wzrost Gospodarczy, 50(2), 163-176.

Skowronek-Mielczarek, A. (2015). Zmiany zachowań małych i średnich przedsiębiorstw w okresie spowolnienia gospodarczego. Warszawa: Oficyna Wydawnicza Szkoły Głównej Handlowej. 
Skowronek-Mielczarek, A. (2016). Reakcja małych i średnich przedsiębiorstw na kryzys. Warszawa: CeDeWe.

Skowronek-Mielczarek, A., Bojewska, B. (2017). Zachowania innowacyjne małych i średnich przedsiębiorstw w warunkach niepewności. Handel Wewnętrzny 3(368), 47-59.

Skórska, A. (2016). Regionalne zróżnicowanie innowacyjności sektora usług w Polsce. Studia Ekonomiczne. Zeszyty Naukowe Uniwersytetu Ekonomicznego w Katowicach, 291, 127-138.

Świtalski, W. (2005). Innowacje i konkurencyjność. Warszawa: Wydawnictwo Uniwersytetu Warszawskiego.

Zadura-Lichota, P. (2015). Innowacyjna przedsiębiorczość w Polsce. Odkryty i ukryty potencjał polskiej innowacyjności. Warszawa: Polska Agencja Rozwoju Przedsiębiorczości.

Zembura, W. (2016). Finansowanie innowacji. Studia Ekonomiczne. Zeszyty Naukowe Uniwersytetu Ekonomicznego w Katowicach, 305, 109-125.

Mateusz Janas, mgr, doktorant, Uniwersytet Ekonomiczny w Krakowie, Wydział Zarządzania. Zainteresowania badawcze autora koncentrują się wokół rozwoju sektora mikro-, małych i średnich przedsiębiorstw, ze szczególnym uwzględnieniem ich konkurencyjności i innowacyjności. W swoich pracach najczęściej porusza zagadnienia związane z internacjonalizacją i emancypacją zagraniczną sektora MŚP. Zawodowo pełni funkcję prokurenta w przedsiębiorstwie produkcyjno-handlowym zajmującym się produkcją i sprzedażą mebli.

Mateusz Janas, PhD student, Cracow University of Economics, Faculty of Management. The author's research interests focus on the development of the micro-, small- and medium-sized enterprises sector, especially those benefiting from their competitiveness and innovation. In his work he most often addresses issues related to internationalisation and foreign emancipation of the SME sector. Professionally, he is a proxy in business activity. The production and commercial company belongs to the SME sector dealing in the production and sale of furniture.

ORCID: 0000-0002-7730-370X

\section{Adres/address:}

Uniwersytet Ekonomiczny w Krakowie Wydział Zarządzania

Katedra Ekonomiki i Organizacji Przedsiębiorstw

ul. Rakowicka 27, 31-510 Kraków, Polska

e-mail: janasmateusz07@gmail.com 